\title{
Ornamental Fishes of Coastal West Bengal, India -Prospects of Conservation and Involvement of Local Fishermen
}

\author{
Abir Lal Dutta ${ }^{1 *}$, Debargha Chakraborty ${ }^{2}$, Sajal Kumar Dey ${ }^{1}$, Ashim Kumar Manna ${ }^{3}$, \\ Pankaj Kumar Manna ${ }^{4}$ \\ ${ }^{1}$ Cell and Developmental Biology Laboratory, Department of Zoology, University of Kalyani, Kalyani, India; ${ }^{2}$ Department of Envi- \\ ronmental Science, University of Kalyani, Kalyani, India; ${ }^{3}$ Khejuri College, Vidyasagar University, Midnapore, India; ${ }^{4}$ Academy of \\ Biodiversity Conservation, Kolkata, India. \\ Email: *abirlaldutta1@gmail.com
}

Received February $21^{\text {st }}, 2013$; revised April $18^{\text {th }}, 2013$; accepted May $2^{\text {nd }}, 2013$

Copyright (c) 2013 Abir Lal Dutta et al. This is an open access article distributed under the Creative Commons Attribution License, which permits unrestricted use, distribution, and reproduction in any medium, provided the original work is properly cited.

\begin{abstract}
This survey has been conducted to study the ornamental fishes of coastal Bay of Bengal, selecting the region from Digha to Talpati, a stretch of $64 \mathrm{Km}$ coastal area. Twenty ornamental fish species were identified in the coastal water bodies in this stretch. Some of them are already established as aquarium fishes and rest demand ornamental piscine status for their unique features and qualities. Some of the ornamental fish species of this area like Brachygobious sua, Gobipterus chuno, Badis badis and Brachydanio rario are endangered due to excessive degradation of local ecosystems. Special care should be taken so that they continue to exist. There are ample justifications to establish ornamental fish industry to support the unemployed youth of the area and protect the piscine biodiversity.
\end{abstract}

Keywords: Ornamental Fish; Piscine Biodiversity; Unemployed Youth; Conservation; Indigenous Species; Coastal Bay of Bengal

\section{Introduction}

The demand of ornamental fishes is increasing remarkably due to their important role in the world trade for fish and fishery production [1,2]. About 288 exotic varieties of ornamental fishes are popular in West Bengal [3]. A few indigenous ornamental fish species are popular among the native people of coastal West Bengal as well as to the aquarium lovers of different countries. Singapore is considered to be a major supplier of ornamental fishes in the international market [4]. Singapore exports about US $\$ 80$ million of ornamental fishes annually [5]. The export of ornamental fishes from India is worth only US\$0.2 million, which is not sufficient with regard to the rising demand of these beautiful colored species in the world ornamental fish market. This may be attributed to the lack of involvement of technical people in ornamental fish farming [4]. A large number of very beautiful ornamental fish species are still neglected which are easily available in the natural waters of coastal Bay of Bengal. Due to

\footnotetext{
*Corresponding author.
}

congenial climatic conditions Kolkata and its surrounding districts have emerged as promising breeding centers for ornamental fish where a considerable number of small fish farmers and amateurs are engaged in this trade [6,7]. The indigenous fish fauna of this state includes a wide variety of small fish, which though are unsuitable for conventional fish farming but could be gainfully utilized as ornamental fish for their attractive coloration and other features [7]. These species are found in different qualities of water bodies, like deep perennial ponds, puddles, annual and seasonal ponds, paddy fields and bheries. Most of the fish species can tolerate variations in temperature, salinity, and $\mathrm{pH}$.

\section{Methods}

The study was conducted during July 2011 to June 2012 from Digha to Talpati, a stretch of $64 \mathrm{~km}$ in length and few (variable) kilometers in width, along the coastal Bay of Bengal in India. This region is located at $21^{\circ} 37^{\prime}$ North to $21^{\circ} 89^{\prime}$ North and $87^{\circ} 29^{\prime}$ East to $87^{\circ} 96^{\prime}$ East of Purbo 
Medinipur district (West Bengal, India). This zone was selected for the study as because it is a very remote and still is an ill developed area of the West Bengal, but is rich in fish diversity. This zone has potential to develop into an indigenous ornamental fish trade centre.

The fish species were collected from ponds, paddy fields, muddy water areas, wetlands and other natural water bodies like low-lying paddy fields by using fishing traps and fine nets. The collected specimen was preserved in $5 \%$ formalin and brought to the laboratory for further study. Wherever possible, potential ornamental species were collected alive and taken to the laboratory for culture in aquarium and earthen vats. The salinity (ranging from 0.5 to $9 \mathrm{ppm}$ ) and $\mathrm{pH}$ (5.8 to 8.2) of the water bodies were measured. Further studies were carried out to know about their food habit, feeding behavior, sexual behavior, parental care, and adaptation in aquarium condition. Reports from interrogation (verbal and questionnaire) were also collected as source of information.

\section{Results}

The fishes selected for our study were Colisa fasciata, Schneider 1801; Badis badis, Hamilton 1822; Oryzias malastigma, Mcclelland 1839; Brachygobius sua, Smith 1931; Lepidocephalichthys guntea, Hamilton 1822; Chanda ranga, Hamilton 1822; Chanda nama, Hamilton 1822; Brachydanio rerio, Hamilton 1822; Scatophagus argus, Linnaeus 1766; Ailia coila, Hamilton 1822; Gobiopterus chun, Hamilton 1822; Puntius ticto, Hamilton 1822; Puntius stigma, Valenciennes 1844; Chela laubuca, Hamilton 1822; Notopterus notopterus, Pallas 1769; Nandus nandus, Hamilton 1822; Aplocheilus panchax, Hamilton 1822; Mastacembelus pancalus, Hamilton 1822; Puntius sarana, Hamilton 1822; Mestacembelus armatus, Scopoli 1777 and Macrognathus aculeatus, Bloch 1786.

\subsection{Colisa fasciata, Schneider 1801}

Has attractive looks with rainbow and greenish colors. Oblique orange or bluish bars are present on the body. Vertical fins with alternating dark spots, anal fin with red margin are present. Sexual dimorphism, nice rhythmic up and down movement, laterally compressed body, with golden yellow oblong prismatic striations makes the fish more attractive. Filliform long extension of the pectoral fin rays makes it elegant. Handy fish, they maintain a wide range of supplemented food acceptability with ability to breed in aquaria, and show a very beautiful parental care. Their average size is about $8-12 \mathrm{~cm}[8]$. They are often found in rice fields in Asia: Pakistan, India, Nepal, Bangladesh and upper Myanmar [9]. They are generally present in large rivers, estuaries, ditches, ponds [10] and lakes.

\subsection{Badis badis, Hamilton, 1822}

It has unique body shape with colourful transverse bands. They occasionally change their body colour. It can camouflage with the bowlike awaiting posture, and have an interesting pairing habit. Hardy fish, can tolerate wide range of water qualities (pH range 6 - 8), salinity and food acceptability. Able to breed in aquarium, average size varies from $6-8 \mathrm{~cm}$. They are generally found in Asia: Bangladesh, Nepal and Ganges River drainage in India, the Mahanadi river drainage; Assam lowlands close to Brahmaputra (Kaziranga, Gauhati, and Dibru River) [11] and also reported from Bhutan [12].

\subsection{Oryzias malastigma, Mcclelland, 1839}

They have a transparent body with glittering silver belly and silvery margin fins. Sexually dimorphic characters are also present. Male shows anal fin rays. Show elegant movement in Shoals, and jolly females breed several times a year and carry bunches of eggs from seven days up to one month. They are very hardy fish, can tolerate wide range of water qualities (temperature, $\mathrm{pH}$ and salinity). Can consume all sorts of natural and supplementary food of both animal and plant origin. They have excellent larvaevore food habit. They are generally found in Asia (Pakistan, India Nepal, Bangladesh and Myanmar).

\subsection{Brachygobius Sua, Smith, 1931}

A tiny fish, 5/6 vertical black bands are present. An idle fish; always remains in resting condition, attached on the glass walls of aquarium. It seems to be the beauty spot of an aquarium. They always bumble, has comparatively large pectoral fin like honey bee. Although very idle, becomes swift and smart at the time of preying. Sometimes they swim gladly with jerking movement. They can camouflage for protection and predation.

\subsection{Lepidocephalichthys guntea, Hamilton, 1822}

In coastal Bengal, the fishermen popularly know L.guntea as loach. Black and brown spots with whitish long stripes along the laterals are present. Most of the time, they remain lazy and stay at the bottom of the aquarium. Its zigzag movement is very fast. The rapid rhythmic movement of operculum makes them attractive in aquarium. As it is detritus feeder, it plays a vital role to keep the aquarium clean. They have a maximum length of about $40 \mathrm{~cm}$. They are very hardy fish which can withstand long starvation. It is distributed in Asia (Pakistan, Northern India, Bangladesh, Nepal, Myanmar and Tha- 
iland.) and also present in Salween basin [13].

\subsection{Chanda ranga, Hamilton, 1822}

Popularly known as Glassfish, they are transparent, with a pearly white spot in the belly. During breeding season it glitters and develops a deeper colour. Its average size is about $4 \mathrm{~cm}$. Wide range of food and $\mathrm{pH}$ acceptability makes them more demandable. They are fresh and brackish water fish generally found in Burma, India, and Thailand.

\subsection{Chanda nama, Hamilton, 1822}

Chanda nama is an established aquarium fish. It is also known as Glassfish but is a little larger than Chanda ranga. With an average size of about $11 \mathrm{~cm}$ and may be male/unsexed [14]. During the breeding season, margin of all fins become glossy white and silvery like neon beam. They usually inhabit standing and running waters, clear streams, canals, beels, ponds, and inundated paddy fields, and are abundant during the rainy season [15]. Wide range of food and $\mathrm{pH}$ acceptability makes them more demandable. They are widely distributed in Asia (Pakistan, India Nepal, Bangladesh and Myanmar).

\subsection{Brachydanio rerio, Hamilton, 1822}

Due to its longitudinal black and white striations, it is popularly know as Zebra fish. In rural West Bengal, it is known as "Hamani" in Birbhum and "Danria" in coastal Medinipur districts. They are very sporty and jolly and show a rhythmic zigzag movement. Brachydanio rerio requires large tank because they are $6 \mathrm{~cm}$ long and need a lot of free swimming space. They are found in shoal. They can tolerate a high degree of toxicity, salinity, turbidity and temperature ( $18^{\circ}$ to $\left.24^{\circ}\right)$ etc. Although it prefers zooplankton, it can also engulf mosquito larvae and tubifex eagerly. In case of food scarcity, it consumes phytoplankton and other aquatic soft weeds. They are easily bred in aquariums. Its colorful body and restless movement attract aquarium lovers. Zebra fish is generally found in the streams of the southeastern Himalayan region, including the countries India, Pakistan, Bangladesh, Nepal, and Myanmar (USGS NAS-Nonindigenous Aquatic Species). It commonly inhabits streams, canals, ditches, ponds, and slow-moving to stagnant water bodies, including rice fields [16].

\subsection{Scatophagus argus, Linnaeus, 1766}

Has a quadrangular strongly compressed body with steep dorsal head profile. Eye moderately large with the tail fins and all other fins are more or less transparent. Violet dark patches are found on the body. Its main food is zooplankton, micro-arthropod and tubefex. Maximum length is $38 \mathrm{~cm}$ [17] and common length is $20 \mathrm{~cm}$ (male/unsexed). Wide range of food and $\mathrm{pH}$ acceptability makes them more demandable. They are already popular as an aquarium fish. Though they comfortably and naturally live in brackish water yet they can easily adopt to freshwater aquarium. They are found in Indo-Pacific: Kuwait to Fiji, north to southern Japan, south to New Caledonia. Reported from Samoa [18], Tonga [19] and the Society Islands [20].

\subsection{Ailia coila, Hamilton, 1822}

It is a small transparent fish and is popularly known as "kajri" in costal Bengal. A prominent and bright black spot present its pectoral fin base, body is elongated and deeply compressed, mouth sub-inferior, upper jaw longer than lower jaw. Barbells are well developed and present in four pairs. Dorsal fin is absent and a small adipose fin present. Their pectoral fins are well developed and pelvic fins are small, Pectoral spine are slender and serrated, anal fin is large. Body color is silvery or whitish [21]. In aquarium they move in shoals with dancing tentacles. Found in India, Pakistan, Nepal and Bangladesh. Maximum length reported, $15.4 \mathrm{~cm}$ [22].

They are mainly plankton feeder and consume all sorts of aquatic micro arthropods and larvae.

\subsection{Gobiopterus chun, Hamilton, 1822}

Although it is an estuarine fish, they are found in fresh and brackish water in the lower courses of rivers. They are generally not found in fish markets. It can be a popular aquarium fish for its exclusively glass like transparent body. They breed throughout the year and are able to live in aquarium. Their average size is about $3.0 \mathrm{~cm}$ [23]. The clutches of eggs are visible in gravid females. Though it is an estuarine fish yet can easily live and breed in freshwater aquarium. They are highly carnivorous fish and prefer micro arthropods and zooplanktons. Its high demand as an aquarium fish is due to its miraculous appearance and sudden camouflaging character. Wide range of food and $\mathrm{pH}$ acceptability makes them more demandable. They are generally found in Asia (Pakistan, India Nepal, Bangladesh and Myanmar).

\subsection{Puntius ticto, Hamilton, 1822}

Puntius ticto is an established aquarium 'barb'. A body with silvery white glittering colour with a black spot on caudal peduncle is present. Maximum size is about 10.0 $\mathrm{cm}$; [10], Wide range of food habit and hardy character makes them popular to the aquarium lovers. The sexual dimorphism and seasonal colour change in breeding period makes them more demanding. Found in still, shallow, marginal waters and rivers, mostly with muddy bottoms. They can feed on crustaceans, insects and planktons. About 150 eggs are laid in a batch and about 20 
batches are laid at a time. They are generally found in Asia (Pakistan, India Nepal, Bangladesh and Myanmar).

\subsection{Puntius stigma, Valenciennes 1844}

Puntius stigma is also an established aquarium 'barb'. They are commonly found in ponds, pools and ditches of Bengal. It usually grows to size of 2 to 3 inches but it attains 5 inches in length. They found in male and female characters. Generally male are well define, they have a deeper colour and extends to the end of the caudal fin, while in the female it is more or less diffuse and only extends up to the end of the caudal peduncle. Usually the female develop this coloration only when theses fishes are ready to lay eggs, while in the male, the colour band develops with the repining of germ cells. The body of mature female is proportionally deeper than male. Wide range of food habit and hardy character makes them popular to the aquarium lovers. Broad range of food and $\mathrm{pH}$ acceptability makes them more demandable. They are generally found in Asia (Pakistan, India Nepal, Bangladesh and Myanmar).

\subsection{Chela laubuca, Hamilton, 1822}

Chela labuca have bilaterally compressed body with longitudinal light stripes. The upper part from the lateral line is olive-green while the lower part is glittering. Its attractive rainbow colour makes it a demanding aquarium fish. They are omnivorous in nature, and can be easily bred in aquarium and maximum size about $17.0 \mathrm{~cm}$. A longitudinal stripe may be present on the body which extends to operculum where it surrounds a deep black blotch. Wide range of food and $\mathrm{pH}$ acceptability makes them more demandable. They are generally found in Asia (Pakistan, India Nepal, Bangladesh and Myanmar).

\subsection{Notopterus notopterus, Pallas, 1769}

Notopterus notopterus is a fresh water knife fish. It can withstand $\mathrm{pH}$ range from 6.0 - 6.5 [24]. Body is bilaterally flat. A large eye with long anal fin is attractive to the aquarium lovers. It has a silvery whitish body and is slow moving. They are highly carnivorous and prefer small fish, larvae and small aquatic arthropods, small crustaceans and zooplanktons. Wide range of food and $\mathrm{pH}$ acceptability makes them more demandable in the aquaria arena. The fingerlings body colour is dark violet which fades with age. Maximum length is about $60.0 \mathrm{~cm}$ male/unsexed [25]; but common length is $25.0 \mathrm{~cm}$ male/unsexed [10] .Found in India, Myanmar, Thailand and Malaysia.

\subsection{Nandus nandus, Hamilton, 1822}

It is a slightly large fish and is yet to be established as an aquarium fish. It has blackish brown colour sometimes with vertical blackish brown bands on the body. They can camouflage with the suitable substratum. They are highly carnivorous and have a protractible jaw with large mouth. They have Maximum size of about $20.0 \mathrm{~cm}$ [10] and can tolerate $\mathrm{pH}$ of 6.9 to 8 . Frequently occur in ditches and inundated fields, they are generally seen in summer. Feeds on aquatic insects and fishes [23]. They are generally found in Asia (Pakistan, India Nepal, Bangladesh and Myanmar).

\subsection{Aplocheilus panchax, Hamilton, 1822}

They are generally Surface feeder and larvaevore fish, present in pair or single. The average size is $9.0 \mathrm{~cm}$ [14].They can breed several times a year. Sticky eggs are attached on aquatic weeds. The males are more attractive with slivery white or orange yellow bordered fins. They are generally present in lowland wetlands to estuaries area [26] and in ponds, ditches and canals [15,27].They are usually found in shallow lagoons and swamps among roots of mangroves along the waters margins [14]. They generally prefer, clear water areas with dense growth of rooted or floating macrophysics [28], sometimes they occurring in hyper saline water and feed mainly on insects [27] so they can be utilized for mosquito control. They are difficult to maintain in aquariums [29]. Wide range of food and $\mathrm{pH}$ acceptability makes them more demandable. They are generally found in Asia (Pakistan, India Nepal, Bangladesh and Myanmar).

\subsection{Mastacembelus pancalus, Hamilton, 1822}

It has a bilaterally compressed body with pointed beak like upper jaw. The upper portion of the body is grayish blue or gray while the lower portion is sandy gray which in mature fish is yellowish. Three to five deep black sports are found at the base of the distal dorsal fins and one spot is present at the base of caudal fin. It is a mud dwelling bottom feeder and habitually stays at the bottom of the aquarium. They usually feed on entomostracans and insect larvae. Maximum length is $13.5 \mathrm{~cm}$ [22]. They generally breed in monsoon period or rainy season and spawn between May and August [30]. In aquaria, they spawn in the upper water-level where courtship between female and slender and smaller male generally take place [10].

\subsection{Puntius sarana, Hamilton, 1822}

It is a minor carp. Size is about $42.0 \mathrm{~cm}$ (male/unsexed); [15] and mostly remain in flock. Bilaterally compressed bodies with slivery white glittering scale are present. $P$. sarana's movement is slow but royal in aquarium. Present in rivers, streams, lakes and backwaters region. Moving in shoals of four or five with each shoal having 
several dozens, they exhibit a beautiful aquarium picture [17] .They feed on aquatic insects, fish, algae and shrimps. They are present in Asia: Afghanistan, Pakistan, India, Nepal, Bangladesh, and Bhutan [10], Sri Lanka [17], Myanmar [31] and Thailand [32].

\subsection{Mestacembelus armatus, Scopoli, 1777}

It looks like Pankal but smaller than Pankal (Mastambullas pancala) and generally a bottom dweller with detritus feeding habit. Body colour is sandy yellow and its shows wavy zigzag moment. Their movement is very catchy. Maximum length is about $90 \mathrm{~cm}$. They are found both in highland streams and low wetlands [26]. Usually found in streams and rivers with sand, pebble, or boulder substrate. Seldom leaves the bottom except when disturbed. Also occurs in still waters, both in coastal marshes and dry zone tanks. Sometimes stays partially buried in fine substrate. They are reported to occur in areas with rocky bottoms in the Mekong mainstream during the dry season, but enter canals, lakes and other flood plain areas during the flood season [33]. They are marketed fresh and frequently seen in the aquarium trade [28]. They can tolerate high range of $\mathrm{pH}$ from 6.5 to 7.5 [34]. They are generally presented in Asia: Pakistan to Viet Nam and Indonesia.

\subsection{Macrognathus aculeatus, Bloch, 1786}

They show features similar to Pankal (Mastambullas pancala) except that they are smaller. In young stage the distal part of the body shows black mosaic, which fades away with the advancement of age. Maximum length is about $38 \mathrm{~cm}$. They are generally freshwater and brackish water fish, and tolerate a high range of $\mathrm{pH}$ from 6.5 to 7.5 [34]. They generally feed crustaceans. Present in Asia: India, Nepal, Thailand, Malay Peninsula, Borneo, Indonesia Bangladesh [15].

\section{Discussion}

Data were obtained from interviewing nine hundred and thirty peoples about the present status of these twenty one colour fishes as well as their situation thirty years back, with regards to their availability. The information considered were those obtained from majority ( $>50 \%$ ) of person interviewed Table 1. Perusal of the responses in the Table1 highlights the fact that most of the fish species show a declining trend with regards to their availability.

In another study two hundred and seventy nine water bodies were considered for the presence or absences of these ornamental fishes from July, 2011 to June 2012 with the help of skilled fishermen. The percentage availability of each species in each water body is given in Table 2. The study revels that most of the species are present at an alarmingly low percentage which calls for immediate restorative measures. The fishes which are lower in availability could be declared as threatened or endangered in this locality.

\section{Identifying the Underlying Causes for the Reduction in the Availability of Theses Ornamental Fishes in the Study Area}

Nowadays the villagers mainly culture Indian major carps (IMC) for gaining more profit. Besides, the people are using enormous chemical pesticides to eradicate carnivorous and weed fishes for major carp cultivation. Sometimes it is a fascination to cultivate different exotic species like silver carp (Hypopthalmycthis molitrix), grass carp (Ctenopharyngoden idella) American rohu (Cyprinus carpio), Telapia (Tilapia mossambica) and ( $T$. nilutica), African magur (Clarias garipinas), java punti (Puntius javanicus) and Pangas (Pangaius sp.) etc. for the purpose of destruction of unwanted weed fishes. It was found, however, that most of the time the ornamental fishes are also consumed by the local population. Thus, these ornamental fishes have to compete with the locally cultivated fishes which serve as food. Indiscriminate use of chemical pesticides and fertilizers in paddy fields, especially for high yielding crop cultivation and aquaculture, is one of the reasons for the decrease in the ornamental fish diversity.

Dewatering of ponds every year is found to be another cause for decrement of ornamental fishes as because they are considered as the natural breeding ground for the coloured fishes where they easily propagate during the rainy season. After dewatering of ponds mud dwelling fishes like Ban (Macrognathuous aculeatum), Pankal (Mystambelus pankalal), Tur (Mas tacembellus), Guntea (Lepidocephalichthys gunte) etc. are collected by the urea exposure over the bottom mud. Exposure to urea inevitably mars any chance for the survival of any ornamental fish remaining in the dewatered pond.

Another factor leading to the decline in the availability seems to be illiteracy and lack of awareness about the significance, both economical and ecological, of theses ornamental fishes among the fishing folk. Rural collectors cannot discriminate between the desired coloured fish species and other trace fish species, which are not useful to the coloured fish market. Therefore, proper strategy for the conservation of these uncustomary biotic resources, especially the endangered and threatened species is needed [8]. Over population is one of the causes for decrease in the number of locally available coloured fishes in the coastal Bay of Bengal.

With the increasing potentiality of ornamental fish farming some fish have a good demand in global fish market for their beautiful coloration and life style [8]. Some of the indigenous ornamental fishes those were 
abundant even in the past decades [35-37] are becoming rare.

It is crucial time to protect the threatened biodiversity and the susceptible indigenous fishes especially the ornamental fish species. It is encouraging that the developing countries contribute to more than $60 \%$ of the total world trade fish market. Although India is still in a marginal position but its market is rising rapidly [8].

Indiscriminate harvesting of fish species from their natural habitat is regularly done by the rural people, which may lead to serious stock depletion. Through interviewing the local people, it is clear that the Lepidocephalichthys guntea, Scatophagus argus, Gobiopterus chun, Oryzias malastigma, Brachygobius sua, Ailia coilia, Mestaeembelus armatus, Macrognathus aculeatus, Mastacembelus pancalus, present in very threatened condition (Table 1), but it is fact that in earlier occasion theses fishes are present in plenty. It is evident especially in case of Puntius sarana which is not available now but was common thirty years back. To overcome this problem these fishes can be reared and breed in captivity and vocational training could be provided to the fisher folk in rural areas for rearing and breeding of those threatened fish [13].

A good number of stake holders are already involved in ornamental fish farming of coastal Bay of Bengal, but there is lack of proper marketing channel in this trade. In most of the cases the rural women and children collect the fishes from the natural habitats. The exporters buy these fishes from the farmers/collectors, against nominal price and export them to the global fish market [8]. Ornamental fish marketing is becoming popular as an easy and stress relieving hobby. About 7.2 million houses in the USA, 3.2 million in the European Union have an aquarium and this hobby is on an increase throughout the world. Presently USA, Europe and Japan have the largest ornamental fish market [8].

However, there is a nice scope to establish an ornamental fish industry to export the aquarium fishes. Ornamental fish farming that includes rearing, captive breeding, and culture have considerable economic importance [35]. Annually, India exports about of 250 million ornamental fishes, mainly to USA [38], with Tamilnadu and West Bengal contributing to about 150 millions and 30 million respectively. A rich fish diversity, favorable climate, cheap labor and easy distribution make India, specially West Bengal, suitable for ornamental fish culture. With kolkata (West Bengal, India) as a nodal distribution and export center, the neighboring districts can become the major ornamental fish-producing zones of India. In the state of West Bengal there are more than 2000 people involved in this trade including ornamental fish breeders, growers, seed and live food collectors. About 150 families are involved in ornamental fish farming to maintain their livelihood. More than 500
Table 1. Status of ornamental fish species (present and thirty years back) through questionnaires.

\begin{tabular}{|c|c|c|c|}
\hline No & Species & \pm 30 years back & 2011 \\
\hline 1 & C. fasciata & Plenty & Common \\
\hline 2 & B. badis & Moderate & Very rare \\
\hline 3 & O. malastigma & Plenty & Plenty \\
\hline 4 & B. sua & Plenty & Very rare \\
\hline 5 & L. guntea & Plenty & Rare \\
\hline 6 & C. ranga & Plenty & Plenty \\
\hline 7 & C. nama & Plenty & Plenty \\
\hline 8 & B. rerio & Plenty & Frequent \\
\hline 9 & S. argus & Common & Rare \\
\hline 10 & A. coila & Plenty & Very rare \\
\hline 11 & G. chuno & Common & Rare \\
\hline 12 & P. ticto & Plenty & Plenty \\
\hline 13 & P. stigma & Plenty & Plenty \\
\hline 14 & C. labuca & Common & Frequent \\
\hline 15 & $N$. notopterus & Plenty & Frequent \\
\hline 16 & N. nandus & Common & Not available \\
\hline 17 & A. panchax & Plenty & Plenty \\
\hline 18 & M. pancalus & Plenty & Rare \\
\hline 19 & P. sarana & Common & Not available \\
\hline 20 & M. armatus & Common & Vary rare \\
\hline 21 & M. sculeatus & Common & Vary rare \\
\hline
\end{tabular}

families use it as an additional income generating business [8].

There is an immense scope of ornamental aquaculture in coastal Bengal, only if the captive breeding of ornamental fish could be commercially done. It can be a good source of earning foreign exchange. Most of the unsold fish or excess of exports can be utilized as food and some fishes have a good domestic market [8].

Some unemployed educated youth of this backward estuarine area of coastal Bay of Bengal may earn considerable amount from this work. Most of these families work as a small home unit, through this cultivation they earn US\$ 50 - 100 monthly. Generally the men are engaged in the seed collection and marketing. However it is the women and children who look after the activities like water exchange; feeding etc [8]. It will be easier, if they form self help group or co-operative, for ornamental fish marketing. Motivation and training can be imparted through the government agencies and NGOs, to take the ornamental fish farming as an alternative employment 
Table 2. Experimental observation: percentage availability of the selected fish species in the water bodies of the study area.

\begin{tabular}{|c|c|c|}
\hline No & Species & (\%) \\
\hline 1 & C. fasciata & $86.22 \pm 1.56$ \\
\hline 2 & B. badis & $4.57 \pm 0.13$ \\
\hline 3 & O. malastigma & $92.47 \pm 1.87$ \\
\hline 4 & B. sua & $7.22 \pm 0.41$ \\
\hline 5 & L. guntea & $12.78 \pm 0.52$ \\
\hline 6 & C. ranga & $81.49 \pm 1.05$ \\
\hline 7 & C. nama & $87 \pm 1.22$ \\
\hline 8 & B. rerio & $30.12 \pm 0.78$ \\
\hline 9 & S. argus & $13.79 \pm 0.24$ \\
\hline 10 & A. coila & $8.47 \pm 0.33$ \\
\hline 11 & G. chuno & $14.75 \pm 0.17$ \\
\hline 12 & P. ticto & $88.58 \pm 0.97$ \\
\hline 13 & P. stigma & $95.2 \pm 0.88$ \\
\hline 14 & C. labuca & $32.42 \pm 1.05$ \\
\hline 15 & $N$. notopterus & $22.87 \pm 0.73$ \\
\hline 16 & N. nandus & $00 \pm 00$ \\
\hline 17 & A. panchax & $8.22 \pm 0.44$ \\
\hline 18 & M. pancalus & $4.78 \pm 0.13$ \\
\hline 19 & P. sarana & $14.87 \pm 0.85$ \\
\hline 20 & M. armatus & $99.44 \pm 1.52$ \\
\hline 21 & M. sculeatus & $2.55 \pm 0.06$ \\
\hline
\end{tabular}

opportunity for this unemployed educated estuarine youth.

\section{Conclusion}

From this study we come to the conclusion that a considerable number of ornamental fish species which are available in the natural water bodies of the coastal Bay of Bengal are in a state of danger in near future. This calls for immediate intervention to prevent the undesired decline of the potentially marketable colourful variety of fishes. This can be done fruitfully with the active participation of the local populations in breeding, marketing, and conservation of theses wonderful fishes. When we engage a good number of skilled educated people in this colour fish farming, it can solve two problems, one is unemployment, and the other is the ecological restorations of the water bodies. This can possibly happen when the local populace is provided with not only encouragement but also active support from the local governing bodies. Formation of self help groups and cooperative marketing strategies will ensure not only considerable income but also self viability. Besides, this will prevent emigration. With this coastal Bay of Bengal area taken as a model area, we can replicate the same in other states.

\section{Acknowledgements}

This work was supported by University of Kalyani, Department of Zoology, Kalyani, Nadia, West Bengal, India, Academy Of Biodiversity Conservation, Bangur Avenue, Kolkata, and Khejuri College, West Bengal, India. I have taken the help from Sukanto majumder, Kaushik sarkar and Pradipta Dubey, Research Scholars of the Department of Zoology, Physiology and Rural Development and Management respectively, University of Kalyani, Kalyani, Nadia, West Bengal, India. I am grateful to Professor C. R. Sahu, Department of Zoology, University of Kalyani, West Bengal, for his support and constant guidance for my work.

\section{REFERENCES}

[1] T. S. Nagesh, J. Barman and D. Jana, "Karyomorphological Study of three Freshwater Ornamental Perches of West Bengal," Journal of Inland Fish Society India, Vol. 36, No. 2, 2004, pp. 45-48.

[2] S. Sarma, B. K. Bhattacharjya, S. G. S. Zaildi and A. Landge, "Indigenous Ornamental Fish Biodiversity of Central Brahmaputra Valley Zone Assam," Journal of Inland Fisheries Society of India, Vol. 36, No. 1, 2004, pp. 29-35.

[3] I. S. Bhaskar, P. S. R. Reddy, B. E. Barithy, R. Subramanion and R. S. Lazarus, "Exotic Fresh Water Aquarium Fishes and Other Role in Aquarium Fish Train in India,” Proceedings Special Publication 1, Indian Branch, Asian Fisheries Society, Mangalore, 1989, pp. 35-39.

[4] M. R. Rajan and N. Karpagam, "Effect of Different Concentrations of Vitamin c on Feed Utilization and Breeding of Certain Live, Breading Ornamental Fishes,” Environment and Ecology, Vol. 22, No. 1, 2004, pp. 31-37.

[5] J. D. Jameson and P. Sonthanam, “Ornamental Fish Culture. The National Symposium for Aquaculture for 2000 (AD),” Madurai Kamoraj University, India Press, Madurai, 1994, pp. 72-87.

[6] A. Ghosh and S. Debnath, "Ornamental Fish Farming-A Lucrative Business for Rural Womenfolk of Some Villages of Howrah, West Bengal,” National Workshop on Aquaculture Economics, 6-8 October 1998, Bhubaneswar.

[7] B. K. Mahapatra, “Ornamental Fish Culture,” Fisheries Research Station, Directorate of Fisheries, Government of West Bengal, Kalyani, Publication No. 10, 1999.

[8] A. Ghosh, B. K. Mahapatra and N. C. Dutta, "Studies on Native Ornamental Fish of West Bengal with a Note on Their Conservation,” Environment and Ecology, Vol. 20, No. 4, 2000, pp. 787-793.

[9] R. L. Welcomme, "International Introductions of Inland 
Aquatic Species,” FAO Fish Technical Paper, 1988, pp. 294-318.

[10] P. K. Talwar and A. G. Jhingran, "Inland Fishes of India and Adjacent Countries,” Vol. 2, Oxford IBH Publishing Co. Pvt. Ltd., New Delhi-Calcutta, 1991, pp. 1027-1028.

[11] S. O. Kullander and R. Britz, "Revision of the Family Badidae (Teleostei: Perciformes), with Description of a New Genus and Ten New Species," Ichthyological Exploration of Freshwaters, Vol. 13, No. 4, 2002, pp. 295372.

[12] K. G. Rajbanshi and I. Csavas, "Aquaculture Development in Bhutan," A Report Prepared for the Establishment of Fish Seed Production Centre Project, 1982, p. 46.

[13] M. Kottelat, "Zoogeography of the Fishes from Indochinese Inland Waters with an Annotated Check-List," Bulletin-Zoologisch Museum, Universiteit van Amsterdam, Vol. 12, No. 1, 1989, pp. 1-55.

[14] A. G. K. Menon, "Check List-Fresh Water Fishes of India,” Record of Zoological Survey of India, Miscellaneous Publication, Occasion Paper No. 175, 1999, p. 366.

[15] A. K. A. Rahman, "Freshwater Fishes of Bangladesh," Zoological Society of Bangladesh, Department of Zoology, University of Dhaka, Dhaka, 1989, p. 364.

[16] R. G. Spence, C. Gerlach, C. Lawrence and C. Smith, "The Behavior and Ecology of Zebrafish, Danio rerio," The Biological Reviews, Vol. 83, No. 1, 2008, pp. 13-34. doi:10.1111/j.1469-185X.2007.00030.x

[17] R. Pethiyagoda, "Freshwater Fishes of Sri Lanka," Wildlife Heritage Trust, Sri Lanka, Colombo, 1991, p. 362.

[18] E. Lieske and R. Myers, "Coral Reef Fishes. Collins Pocket Guide” Haper Collins Publishers, 1994, p. 400.

[19] J. E. Randall, J. T. Williams and D. G. Smith "Checklist of the Shore and Epipelagic Fishes of Tonga," Atoll Research Bulletin, Vol. 502, No. 1, 2003, pp. 497-508.

[20] G. R. Allen, "Field Guide to the Freshwater Fishes of New Guinea,” Christensen Research Institute, Madang, 1991.

[21] S. M. Galib, “A Study on Fish Diversity and Fishing Gears of Chalan Beel with Reference to Preservation of Catches Honors Dissertation,” Department of Fisheries, University of Rajshahi, Rajshahi, 2008, p. 172.

[22] A. K. A. Rahman, "Freshwater Fishes of Bangladesh," 2nd Edition, Zoological Society of Bangladesh, Department of Zoology, University of Dhaka, Dhaka, 2005.

[23] W. J. Rainboth, "Fishes of the Cambodian Mekong," FAO Species Identification Field Guide for Fishery Purposes, FAO, Rome, 1996, p. 265.

[24] T. R. Roberts, "Systematic Revision of the Old World Freshwater Fish Family Notopteridae,” Ichthyological
Exploration of Freshwater, Vol. 2, No. 4, 1992, pp. 361383.

[25] M. Kottelat, A. J. Whitten, S. N. Kartikasari and S. Wirjoatmodjo, "Freshwater Fishes of Western Indonesia and Sulawesi,” Periplus Editions (HK) LTD., Indonesia, 1993, p. 344.

[26] C. Vidthayanon, "Peat Swamp Fishes of Thailand,” Office of Environmental Policy and Planning, Bangkok, 2002.

[27] K. K. P. Lim and P. K. L. Ng, “The Freshwater Fishes of Singapore” Singapore Science Centre, Singapore City, 1990, p. 160.

[28] W. J. Rainboth, "Fishes of the Cambodian Mekong," FAO Species Identification Field Guide for Fishery Purposes, FAO, Rome, 1996.

[29] J. H. Huber, "Updated Checklist of Taxonomic Names, Collecting Localities and Bibliographic References of Oviparous Cyprinodont fishes (Atherinomorpha, Pisces)," Société Française d'Ichtyologie. Muséum, National d’Histoire Naturelle, Paris, 1996, p. 399.

[30] M. Shafi and M. A. A. Quddus, "Bangladesher Matshya Sampad (in Bengali),”Bangla Academy of Dhaka, Dhaka, 1982, pp. 314-319.

[31] W. Oo, "Inland Fisheries of the Union of Myanmar," In: T. Petr and D. B. Swar, Eds., FAO Fish, Technical Paper 2002, p. 431.

[32] A. Sidthimunka, "A Report on the Fisheries Survey of the Mekong River in the vicinity of the Pa Mong Dam Site," Inland Fisheries Division, Department of Fisheries, Bangkok, 1970, p. 75.

[33] C. Sokheng, C. K. S. Chhea and K. Viravong, (AMFC), AMFP Report 2/99, P.D.R., Vientiane, 1999.

[34] K. Riede, "Global Register of Migratory Species—From Global to Regional Scales," Final Report of the R\&DProject 80805 081, Federal Agency for Nature Conservation, Bonn, 2004, p. 329.

[35] A K. Manna and S. Banerjee, "Sexual Dimorphism in the Cyprinedontied Weed Fish Oryzias melartigma,” Science \& Culture, Vol. 50, No. 4, 1984, p. 329.

[36] T. Paria and A. K. Manna, "Length Weight Relationship \& Fecundity of a Tiny Gobiod Fish Brachygobius sue," Environment and Ecology, Vol. 20, No. 4, 2002, pp. 858861.

[37] T. Paria, S. K. Ghosh and A. K. Manna, "Behavior Patterns of Bumble Bee Fish. Brachygobius sua," Environment and Ecology, Vol. 15, No. 4, 1997, pp. 935-339.

[38] A. K. Manna, "Infection of Anchor Worm Lernaea on a New Fish Host Brachygobius suh,” Environment and Ecology, Vol. 7, No. 2, 1989, pp. 497-498. 